\title{
40. Y1lında Türkiye Muhasebe Eğitimi Sempozyumu
}

\section{$40^{\text {th }}$ Year of Accounting Education Symposium of Turkey}

\author{
Duygu $\operatorname{Has}^{1}$ (D), Ceren Dinçel ${ }^{1}$ (D), Hande Kaygusuzoğlu ${ }^{1}$ (i) \\ ${ }^{1}$ Arş.Grv. İstanbul Üniversitesi İşletme Fakültesi, Muhasebe Anabilim Dalı, İstanbul, Türkiye \\ ORCID: D.H. 0000-0002-6975-2230; C.D. 0000-0002-3665-2452; H.K. 0000-0003-1591-262X
}

ÖZ

Türkiye Muhasebe Eğitimi Sempozyumu (TÜRMES), senede bir defa Türkiye'deki muhasebe öğretim elemanlarını ve meslek mensuplarını bir araya getiren önemli bir bilimsel organizasyondur. Bu sempozyum muhasebedeki güncel konuların anlatılıp tartışılmasında, konuşmacıların ve dinleyicilerin birbirini tanımasında ve aktif bir iletişim ağı kurmasında büyük bir rol oynamaktadır. Bu sene 40. yılına ulaşan bu sempozyumda, Türkiye'de 1979'dan 2019 yılına kadar muhasebe mesleğinin ve eğitiminin gelişimi anlatılmış ve muhasebenin geleceği tartışılmıştır. Bu yazıda, 19-23 Nisan 2019 tarihlerinde sunulan bildiriler özetlenmiş ve sempozyuma iliş̧in genel bir değerleme yapılmıştır.

Anahtar kelimeler: Muhasebe, TÜRMES, Muhasebe Eğitimi

\section{ABSTRACT}

The Accounting Education Symposium of Turkey (TURMES) is an important scientific organization that brings Turkish academics and professionals in the accounting field together, once a year. This symposium plays a major role in explaining and discussing current issues in accounting as well as in allowing speakers and attendants to get to know each other, and in establishing an active communication network. In this symposium, which has reached its $40^{\text {th }}$ year this year, the development of the accounting profession and accounting education in Turkey from 1979 to 2019 are described and the future of accounting is also discussed. In this paper, proceedings which were presented during the period of 19-23 April 2019 were summarized and a general evaluation about the symposium was made.

Keywords: Accounting, TURMES, Accounting Education

\section{Giriş}

İstanbul Üniversitesi İşletme Fakültesi Muhasebe Enstitüsü tarafından 1979 yılında başlatılan Türkiye Muhasebe Eğitimi Sempozyumları kırkıncı yılına ulaşmıştır. Sıralamada XXXVIII: Türkiye Muhasebe Eğitimi Sempozyumu olarak yerini alan toplantı 19-23 Nisan 2019 tarihlerinde Denizli'nin Pamukkale ilçesinde yapıldı. Bu yıl, yine Muhasebe Enstitüsü tarafından düzenlenen ve çok sayıda üniversite ve meslek kuruluşunun katkısı ile gerçekleştirilen sempozyumun konusu sempozyumun ilk düzenlenme tarihine atfen "Kırk Yılın Muhasebesi” olarak seçilmiş ve sempozyumun temel amacı "geçmişimizi bilmek, bugünümüzde nerede ve ne yapmakta olduğumuzu görmek ve geleceğimizde muhasebe mesleğini ve meslek mensuplarını nelerin beklediğini” nin tartışılıp konuşulması olarak tanımlanmıştır. Bu sebeple 19-23 Nisan tarihlerinde üç gün süre ile çok sayıda katılımcı tarafından ilgili konularla toplamda 25 bildiri sunulmuştur.

Muhasebe Enstitüsü Müdürü Prof. Dr. Göksel Yücel'in “Hoşgeldiniz” girişiyle başlayan sempozyumda, İstanbul Üniversitesi Rektörü Prof. Dr. Mahmut Ak İstanbul Üniversitesi İşletme Fakültesi Dekanı Prof. Dr. Recep Pekdemir, TÜRMOB Genel

Başvuru/Submitted: 16.07.2019 Kabul/Accepted: 18.07.2019

Sorumlu yazar/Corresponding author: Ceren Dinçel / ceren.dincel@istanbul.edu.tr

Atıf/Citation: Has, D., Dinçel, C. ve Kaygusuzoğlu, H. (2019). 40. yılında Türkiye muhasebe eğitimi sempozyumu. Muhasebe Enstitüsü Dergisi Journal of Accounting Institute, 61, 113-124. https://doi.org/10.26650/MED.2019592663 
Başkanı A. Masis Yontan, İSMMMO Yönetim Kurulu Başkanı Yücel Akdemir, İstanbul YMMO Oda Sekreteri Sabri Tümer, Denizli SMMMO Yönetim Kurulu Başkanı Himmet Yavaş, MÖDAV Yönetim Kurulu Başkanı Prof. Dr. Can Şımga Muğan, MUFAD Yönetim Kurulu Başkanı Prof. Dr. Ümit Gücenme Gençoğlu ve son olarak Sempozyum Başkanı Prof. Dr. Fatih Yılmaz açış konuşmalarını yapmıştır. Açış konuşmalarının ardından, bu sempozyumların düzenlenmesinin fikir sahibi Prof. Dr. Mustafa A. Aysan, geçmişten beslenen ve bizleri geleceğe taşıyan bildirisi ile değerli görüşlerini ve değerlendirmelerini sunmuştur. Aysan, sunuş bildirisinde paranın geleceği konusuna değinmiş, son yıllarda dijitalleşme ve teknolojik gelişmelerin etkisi ile tüm dünya para tarihinin üçüncü aşaması olan elektronik para ve sanal ekonomi çağına girmekte olduğumuzu belirtmiştir. Bu yeniçağda muhasebecileri, toplumları ve dünya ekonomilerini bilgisayar kullanımının hızlandığı, küreselleşmenin hız kazandığg, ticari yaşamın gereksiz kurallardan ayıklandığ1 ve ortak bir elektronik para ihtiyacının şiddetlendiği bir ortamın beklediğini vurgulamıştır. Prof. Dr. Mustafa A. Aysan değişen bu ortamda İşletme Tarihi, Muhasebe Tarihi kürsülerinin kurulmasını, bir İşletme Yüksek Lisansı okulu, ya da fakültesinin kurulması, bir Muhasebe Uzmanlığı Yüksek Lisansı okulunun kurulması ve bir “elektronik para sistemi”nin kurulması üzerine çalışmalar yapılmasının gerekli olduğunu belirtmiştir.

Prof. Dr. Mustafa A. Aysan’ın sunuş bildirisinden sonra İstanbul Üniversitesi Rektörü Prof. Dr. Mahmut Ak tarafından hem kırk yıl önce, 1979 yılında ilk sempozyumda, hem de bu sene düzenlenen sempozyumda bulunan 13 kişiye plaket takdimi yapılmıştır. Prof. Fikret Öcal, Prof. Dr. Mustafa A. Aysan, Prof. Dr. Ömer Lalik, Prof. Dr. Vural Akarçay, Prof. Dr. Tuna Taner, Prof. Dr. Berna Taner, Prof. Dr. Peyami Çarıkçığlu, Dr. Tülay Aner, Prof. Dr. Göksel Yücel, Prof. Dr. Ahmet Hayri Durmuş, Prof. Dr. Ahmet Yüksel, Prof. Dr. Ülkü Ergun ve Dr. Masum Türker plaketlerini almışlardır.

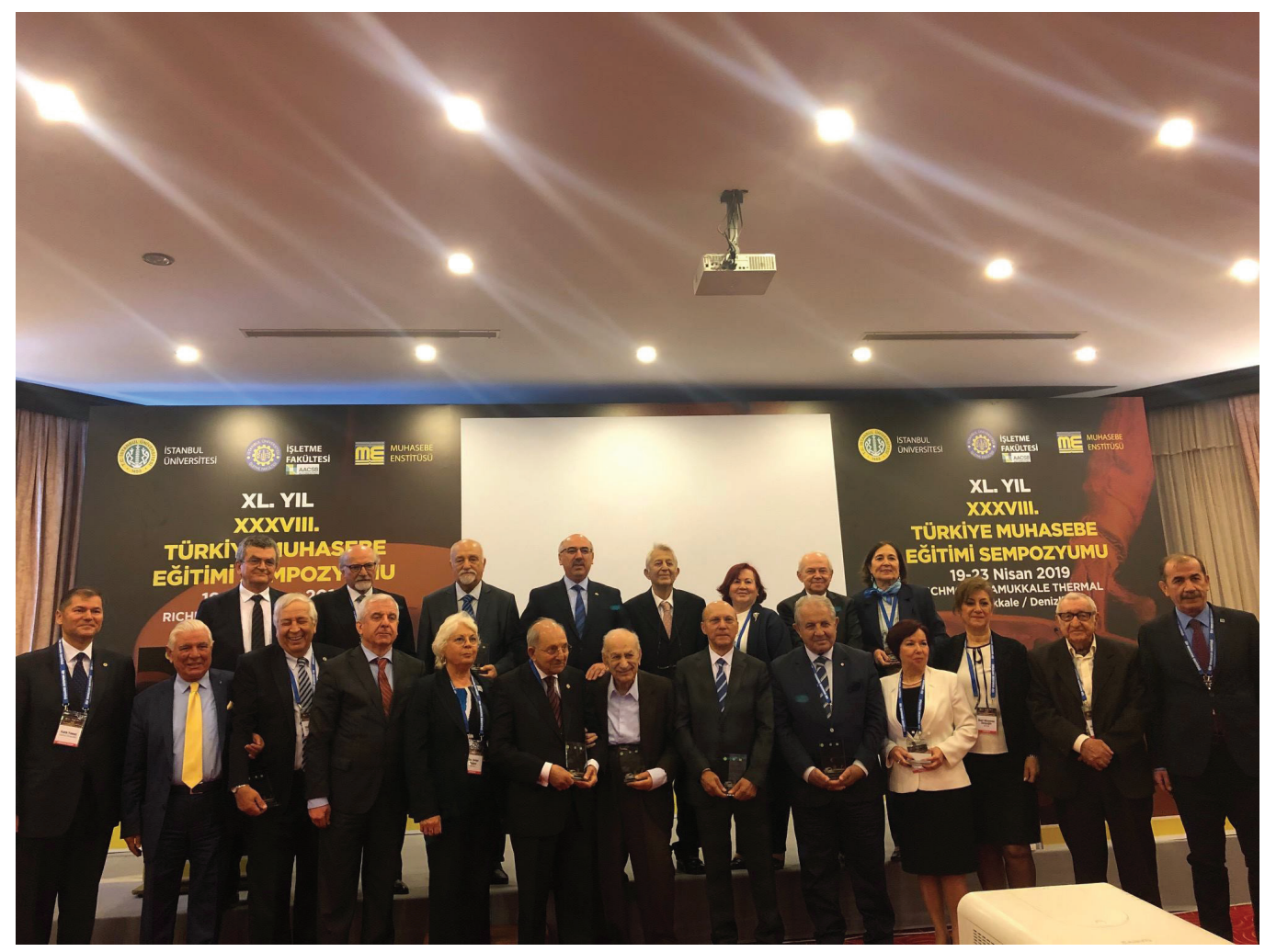

Hem kırk yıl önce, 1979 yılında ilk sempozyumda, hem de bu sempozyumda bulunan 12 kişiye İstanbul Üniversitesi Rektörü Prof. Dr. Mahmut Ak’ın plaket takdimi sonrası. Üst sıra soldan: Recep Pekdemir (İÜ İşletme Fakültesi Dekanı), Ömer Lalik, Vural Akarçay, Mahmut Ak (İ̈̈ Rektörü), Tuna Taner, Berna Taner, Peyami Çarıkçığlu, Tülay Aner. Ön sıra soldan: Fatih Yılmaz (Sempozyum Başkan1), Sabri Tümer (İYMMO Sekreteri), Göksel Yücel (İ̈̈IF Muhasebe Enstitüsü Müdürü), Masis Yontan (TÜRMOB Başkan1), Can Şımga Muğan (MÖDAV Başkanı), Mustafa A.Aysan, Fikret Öcal, Ahmet Hayri Durmuş, Ahmet Yüksel,

Ülkü Ergun. Ümit Gücenme Gençoğlu (MUFAD Başkan1), Oktay Güvemli, Himmet Yavaş (Denizli SMMMO Başkanı) 
Plaket takdiminden sonra İstanbul Üniversitesi İşletme Fakültesi öğretim üyesi Prof. Dr. M. Sema Ülker 2017-2018 eğitim öğretim yılında Yönetim Muhasebesi dersi alan öğrencileri arasında yapılan "Poster Yarışması"nı tanıtmıştır. Yarışma kapsamında toplamda yaklaşık olarak 60 posterin hazırlandığı ve içlerinden en iyi 24 tanesinin finale kaldığını söylemiştir. Düzenlenen bu yarışmanın öğrencilerin yönetim muhasebesi dersinde anlatılan kavramları ve problemleri bir üretim firmasını gezerek tecrübe edinme imkanı bulduklarına ve öğrencilerin edinmiş oldukları bu tecrübenin kendilerini olumlu yönde etkilediği, öğrencilerin derste daha motive ve istekli olduğunu gözlemlediğini söylemiştir. Bu tip çalışmaların öğrencilerin öğrenim beceresini geliştireceğine inandığını belirtmiştir.

\section{"DÜNÜMÜZ"}

Sempozyumda birinci gün bildirilere geçmeden önce Prof. Dr. Ömer Lalik "Dünümüz” konulu yer aldığı özel oturumda, sempozyumların yapıldığı ilk yıl olan 1979 senesinden günümüze kadar acı ve tatlı tecrübelerini ve anılarını katılımcılarla paylaşmıştır. 1979 yılındaki ilk sempozyuma katıldığında bugünlere kadar devam edebileceğini hayal edemediğini belirtmiş ve 40.yllında Türkiye Muhasebe Eğitimi Sempozyumunda yer almaktan büyük mutluluk duyduğunu ifade etmiştir.

Sempozyumun birinci gününün sabah oturumunda “Muhasebe Meslek Örgütlenmesinin Türkiye'deki Tarihi ve TÜRMOB'un Mesleki Eğitimdeki Yeri” konulu ilk bildirisini sunan Pamukkale Üniversitesi İktisadi ve İdari Bilimler Fakültesinden Dr. Öğr. Üyesi Mehmet Utku, bildirisinde ilk önce Türkiye'deki meslek örgütlenmesinin gelişimine ve tarihçesine yer vermiştir. Türkiye Cumhuriyeti'nin kuruluşundan günümüze kadar meydana gelen gelişmelere, çıkan yasalara ve yasal düzenlemelere ve muhasebecilerin dernekleşme faaliyetlerine değinmiştir.

Utku, bildirinin ana kısmında ise 3568 sayılı Meslek Yasasının yürürlüğe girmesi ile kurulan TÜRMOB’un meslek mensuplarına verdiği eğitimlerden bahsetmiş̧tir. Son dönemde gerçekleştirilen eğitimlerin temel konuları ise dönem sonu işlemleri - muhasebe uygulamaları; e-fatura, e-defter, e-arşiv ve e-tebligat uygulamaları; bilanço okuma teknikleri ve finansal; verileri değerlendirme; iş hukuku ve özellikli durumlar; güncel mesleki konular; mali tabloların oluşturulması, analizi ve yorumlanması; gelir vergisi beyanı ve kurumlar vergisi beyanı; vergi incelemelerinde mükellef hak ve yükümlülükleri; iş ve sosyal güvenlik hukuku; genel teşvik uygulamaları; yapılandırma yasalarına yönelik eğitimler; dış ticaret seminerleri; Türk ticaret kanunu eğitimleri; inşaat işlerinde muhasebe ve vergi uygulamaları; meslekte kurumsallaşma ve müşteri odaklı hizmet sunumu; uluslararası finansal raporlama standartları eğitimi; etik eğitimleri; bilirkiş̧ilik eğitimleri; bağımsız denetçilik eğitimleri; konkordato komiserliği eğitimleri başlıkları altında toplanmıştır. Bunların haricinde sürekli mesleki eğitimlerin üzerinde durularak amaçları ve önemi anlatılmıştır.

Bildiri sahipleri Dr. Öğr. Üyesi Mehmet Utku ve Denizli SMMO Dr. Emin Kurtcebe tarafından yapılan çalı̧̧maya göre Denizli SMM Odasınca 2009-2018 yılları arasında toplam 150 tane eğitim gerçekleştirilmiştir. Verilen eğitimlerin meslek mensuplarının ihtiyaçları ve istekleri doğrultusunda yapılmış olduğuna değinilmiştir. Buna paralel olarak aynı çalışmanın sonucunda verilen eğitimler incelendiğinde Luca Bilgisayarlı Muhasebe Eğitimlerinin en fazla verilen eğitim olduğu görülmüştür. Muhasebe mesleğinin şuan yaşamakta olduğu değişimle doğru orantılı olarak meslek mensuplarının bu on yıllık süreç içerisinde en fazla e-dönüşüm ile ilgili eğitimlere katıldığı tespit edilmiştir.

Sempozyumun birinci günün sabah oturumunda “UFRS'nin Türkiye'deki Tarihsel Gelişimi ve UFRS'ye Geçişin Firmaların Finansal Performansları Üzerindeki Etkileri" konulu ikinci bildirisini sunan Pamukkale Üniversitesi Buldan Meslek Yüksek Okulundan Dr.Öğr.Üyesi Yusuf Kaya bildirisinde önce Türkiye’de Uluslararası Finansal Raporlama Standartlarına geçiş sürecine değinmiş ve UFRS ile birlikte finansal raporlamada meydana gelen standardizasyondan bahsetmiş̧ir.

Bildiri sahibi Kaya, çalışmasının amacının UFRS’nin, şirketlerin finansal performansları üzerindeki etkisini ölçmek olduğunu ve araştırmanın konusunun Türkiye ve Almanya sanayi endekslerinde işlem gören şirketler olduğunu belirtmiştir. Çalışmada 1995-2014 arasında 20 yıllık süreçte verilerine ulaşılabilen 36 Alman, 103 Türk sanayi firması örneklem olarak seçilmiş ve bu firmaların finansal tabloları analiz edilmiştir. 
Firmaların UFRS öncesi 3 yıl ve UFRS sonrası 3 yıldaki finansal oranlar arasındaki değişimlerin incelenmesi sonucunda Alman firmalarının kârlılık oranları dışındaki diğer oranlarında meydana gelen değişimlerin anlamlı olmadığı, Türk firmalarında ise cari oran, asit-test oranında anlamlı değişimlerin olduğu belirtilmiştir. UFRS öncesi 10 y1l ve UFRS sonrası 10 yıl finansal oranlar arasındaki değişimlerin incelenmesi sonucunda Türk firmalarında Alman firmalarına göre yine daha fazla anlamlılık ortaya çıktığına değinilmiştir. Bildiriyi sunan Yusuf Kaya, bu durumun sebebinin Almanya'da UFRS'ye 2005 yılından önce gönüllü olarak geçen şirketlerin olduğunu, Türkiye’de ise Avrupa Birliği uyum yasaları çerçevesinde zorunlu geçişin yaşandığg 2005 yılından sonra şirketlerin finansal tablolarının UFRS'ye uygun hale gelmiş olmasından kaynaklandığını savunmuştur.

Sempozyumun birinci günün sabah oturumunda "1979-2018 Yıllarl Arasında Türkiye Muhasebe Eğitimi Sempozyumlarında Sunulan Bildirilerin Metodolojilerinin Incelenmesi” konulu üçüncü bildirisini sunan Dokuz Eylül Üniversitesi Sosyal Bilimler Enstitüsünden Mithat Rasgen Muhasebe Eğitim Sempozyumlarının muhasebe alanında yaşanan gelişmeleri ve değişimleri tespit edip, muhasebe eğitimindeki sorunlara yeni çözüm ve öneriler getirerek "muhasebe eğitimi” hakkında birçok bilimsel çalışmanın yapılmasına öncülük ettiğini vurgulamıştır. Buradan yola çıkarak, bildiri sahipleri 1979 yılından günümüze kadar düzenlenen Türkiye Muhasebe Eğitimi Sempozyumu’nda sunulmuş bildirilerin içerik analizi gerçekleştirmiştir. Mithat Rasgen araştırma kapsamında 433 bildiri incelediklerini söylemiş ve bu bildirileri y1l, konu içerikleri, düzenleyen ev sahibi ve araştırma yöntemi gibi temel sınıflandırmalar altında incelediklerini belirtmiştir.

Araştırmanın bulgularında yıllara göre dağılım incelendiğinde 1990 yılının en fazla bildiri sunulan yıl olduğu görülmüştür. Ev sahiplerine göre sempozyum dağılımında ise sekiz kez Türkiye Muhasebe Eğitim Sempozyumunu gerçekleştirerek sempozyuma en fazla ev sahipliği yapan okul İstanbul Üniversitesi olmuştur. Sunulan bildirilerin konularına göre dağılımına bakıldığında ise "muhasebe eğitimi”nin temel konu başlığı olduğu görülmüştür. Bunu takiben "muhasebe uygulamaları” ve "muhasebenin geleceği”" konuları sırasıyla en fazla işlenen konular olmuştur. 42 katılımcı ile İstanbul Üniversitesi sempozyuma en çok katılımcı gönderen üniversite olmuştur. Bildirilerin içerik dağılımına bakıldığında ise "muhasebe eğitimi” konusu 254 bildiri ile en fazla çalışılan konu olmuş ve bunu sırasıyla "muhasebe eğitimi ve teknoloji”, "muhasebe eğitimi ve kalite", "muhasebe eğitimi ve bankacılık" ve "muhasebe eğitimi ve etik" konuları takip etmiştir. Bildirilerde en çok kullanılan araştırma yöntemi ise sunulan 433 bildirinin \%62'sinde başvurulmuş olan inceleme yöntemi olmuştur. İnceleme yöntemini ise \%19'luk bir oranla anket yöntemi takip etmektedir.

Son olarak Rasgen, son dönemlerde ise teknoloji konusun sempozyumlarda sürekli olarak işlenen bir konu hale geldiğini ve ileride düzenlenecek olan sempozyumlarda da çokça bahsedileceğini öngörmüştür.

Sempozyumun öğleden sonraki “Ortadoğu ve Batı Avrupa Muhasebe Kültür Dengeleri” konulu ilk bildiriyi sunan Prof. Dr. Oktay Güvemli muhasebenin 8.yy ve 18.yy arasındaki gelişimini katılımcılarla paylaşmıştır. Bildirisinde ilk öncesi merdiven yönteminden bahseden Güvemli, Abbasilerin bulmuş olduğu bu yöntemin Osmanlı İmparatorluğu zamanında en mükemmel hali ile kullanıldığını belirtmiştir. Orta Doğu'da hızla gelişim gösteren muhasebenin 1300'lü yıllarda kitapları yazılırken, Batı Avrupa'da ise çift taraflı kayıt sisteminin yeni doğduğuna değinmiştir. Avrupa'daki bu gelişmeleri Luca Pacioli'nin 1494 yazmış olduğu Summa de Arithmetica Geometria Proportioni e Proportionalita kitabı-Batıdaki ilk muhasebe kitabı olarak- takip etmiştir. Sunumuna Cenevizlilerin ticaret hayatının muhasebenin gelişimine sağladığ katkıları ile devam eden Güvemli daha sonra Amerika ve Avrupa'da yaşanan gelişmelere değinip, Osmanlı İmparatorluğundaki gelişmelere ağırlık vererek sunumunu sonlandırmıştır.

Sempozyumun birinci günün öğleden sonraki oturumunda "Ticaret Ortaokullarl ve Ticaret Liselerinin Cumhuriyetin İlk Kırk Yllındaki Gelişimi (1923 -1959)" konulu ilk bildirisini sunan Trakya Üniversitesi İktisadi ve İdari Bilimler Fakültesinden Prof. Dr. Batuhan Güvemli çalışmalarının amacının 1923-1959 yılları arasındaki sürecin ticaret okulları nezdinde ayrıntılı olarak incelenmesi olduğunu söylemiştir. Ticaret ortaokulları ve liselerinin en kaliteli eğitimlerini 1943-1959 döneminde verdiklerini vurgulamış ancak zaman içerisinde (1959 - 1982) oluşturulan İktisadi ve Ticari İlimler Akademileri ve bağlı okullar işletme ve muhasebe eğitimini Anadolu'ya yaygınlaştırmıştır olduğuna değinmiş, ticaret liselerinin de buna paralel bir düşüş yaşadığına ve giderek ticaret meslek liseleri haline dönüştüğünü savunmuştur. 
Sempozyumun birinci günün öğleden sonraki oturumunda "Ezerskiy'in Muhasebede Önerdiği Üçlü Kayıt Sistemi Üzerine Bir Değerlendirme" konulu ikinci bildiriyi sunan Ankara Hacı Bayram Veli Üniversitesi İktisadi ve İdari Bilimler Fakültesinden Prof. Dr. Yıldız Ayanoğlu, Rus iktisatçı, muhasebeci ve din adamı F.V. Ezerskiy’nin üçlü kayıt yöntemini geliştirme gerekçelerine değinmiş, sistemin özelliklerini örneklerle açıklamış, çift taraflı kayıt yöntemiyle karşılaş̧ırmış ve başarısız olma nedenlerini tartışmıştır. Ayanoğlu, üçlü kayıt sisteminde tüm işlemlerin Kasa, Mevcutlar ve Sermaye olmak üzere üç hesapta izlenmesi sistemin basitliğini, ekonomik işlemlerin artış-azalış şeklinde kaydedilmesi anlaşılabilirliğini ve raporun özet bir biçimde sunulması kolaylığını sağlamakta olduğunu düşünmüştür. Ve üçlü kayıt sisteminin temel avantajının, muhasebe eğitimi olmayan kişiler için anlaşılabilir ve basit olması olduğunu savunmuştur. Bu bağlamda Ezerskiy’in sunduğu muhasebe ilkelerinin: anlaşılabilirlik, özet raporlama, tam açıklama ve doğrululuk olduğu belirtilmiştir. Ancak işlemlerin nakit esasında yapılmasından dolayı alacakların ve borçların dikkate alınmaması üçlü kayıt sisteminin en önemli eksikliği olduğu, bir başka problemin ise üretim maliyetinin belirlenmesinde kullanılacak maliyet hesaplarının bu sistemde yer almaması, giderlerin de ödenmedikçe maliyetlere dahil edilmemesi olduğu yine değinilen konular arasında yer almaktadır.

Sempozyumun birinci günün öğleden sonraki oturumunda "2013-2018 Yllları Arasında Türkiye’de Muhasebe Alanında Yapılan Lisansüstü Tezlerin İncelenmesi“ "konulu son bildiriyi sunan Türk Hava Kurumu Üniversitesi İşletme Fakültesinden Öğr.Gör. Funda Karaarslanoğlu ülkemizdeki üniversite sayılarının artmasına paralel olarak lisansüstü eğitim programlarının da arttığını ve bunların genel sonucu olarak da bilimsel araştırmaların her gün daha da artarak devam ettiğini vurgulamıştır. Bu bağlamda bildiri sahipleri tarafından son altı yıldaki 67'si doktora, 526'sı yüksek lisans olmak üzere toplamda 623 adet lisansüstü tez incelenmiş ve bu tezlerin çalışma türü, konusu, tez sahibinin cinsiyeti, tezin sahip olduğu üniversite gibi dağılımları ortaya konulmuştur.

Araştırmanın bulgularına göre araştırma kapsamındaki yıllara göre dağılımda 161 adet ile en fazla tezi 2015 yılında ve 46 adet ile en az tezin 2018 yılında hazırlandığı tespit edilmiştir. En fazla yüksek lisans tezi 102 adet ile Okan Üniversitesi tarafından hazırlanmış, bunların 100 tanesi yüksek lisans ve kalan 2 tanesi doktora tezinden oluşmaktadır. Cinsiyetlere göre dağılımda ise yazılan yüksek lisans tezlerinin \%34,4'ü kadın ve \%60,6'sı erkekler tarafından hazırlanmış ve doktora tezlerinde ise yine benzer bir durumla karşılaşılmış olup, yazılan doktora tezlerinin \%33’ü kadınlar \%67’i erkekler tarafından hazırlandığı Funda Karaarslanoğlu tarafından belirtilmiştir. Konulara göre dağılımda ise yüksek lisans tezlerinde en çok çalışılan konu \%15,1 ile muhasebe uygulamaları olurken, doktora tezlerinde $\% 23,7$ ile standartlar en çok çalışılan konu olmuştur. Tezlerin türüne göre dağılım yapıldığında ise muhasebe alanında yüksek lisans tezlerinin $\% 75,5$ 'inin nitel, \%24,5'inin ise nicel çalışma olduğu görülmüştür. Doktora tezlerinde yine benzer bir durum görülmüş ve tezlerin \%68'inin nitel, \%27,9’unun nicel çalışma olduğu tespit edilmiştir.

Bildiri sunumunun sonunda Karaarslanoğlu, doktora tez sayısının yüksek lisans tez sayısından az olmasını akademik çalışma yapanların oranın az olmasından kaynaklandığını vurgulamıştır.

\section{"BUGÜNÜMÜZ"}

Bugünümüz başlı̆̆ı ile yürütülen ikinci gün programı 21 Nisan günü yine aynı isimli Bugünümüz özel oturumu ile Prof. Dr. Cengiz Erdamar başkanlığında Prof. Dr. Haluk Sumer ve Prof. Dr. Metin Sağmanlı’nın katılımı ile gerçekleştirilmiştir. Sunum içerisinde dijitalleşmenin, günümüz küreselleşen dünyasında işletmelerin yeniden şekillenmelerinde rol oynayan en önemli unsur olarak göze çarptığı belirtilmiştir. Sanal ağ teknolojisinin 2000'li yıllarda yayılması ile birlikte başlayan 4 . Sanayi Devrimi'nin yerini, Blockchain'in doğuşu ve getirdikleri ile beraber 5. Sanayi Devrimi'nin almaya hazırlanması; hem muhasebede hem de işletmelerin tüm birimlerinde baş döndürücü hızda bir dijital dönüşümü beraberinde getirdiği belirtilmiş, tüm bunlarla beraber, bilinen birçok tanımın tekrar yapılması gerekliliği öne sürülmüştür. Artık büyük şirketlerin ağır imalat sektöründe faaliyet gösteren; hantal aktif büyüklüklerine sahip değil; bilanço aktiflerinin nispeten çok daha duru; fakat oldukça derin know-how'a sahip start-up'lar olduğu saptanmıştır.

Dijitalleşmenin bu denli hızlı gelişimi, beraberinde birçok soru işaretini de getirmektedir. Bunların en başında ise, gündemi de bir süredir meşgul etmekte olan; "meslekler gelecekte ne ile karşılaşacak?" sorusu gelmektedir. Konuyla ilgili olarak, 
2013 yılında Frey ve Osborn tarafından yapılan araştırma sonuçlarına göre, birebir insan ilişkilerine dayalı mesleklerin kaybolma ihtimallerinin daha düşük görüldügü bildirilmiştir. Buna mukabil, muhasebe elemanları ve denetçilerin yerlerini bilgisayarların alma ihtimali \%94 olarak saptanmıştır. Tüm bunların, kamuoyunu da kutuplara ayırmakta olduğu ve bir ikilem yarattığı kanısı dile getirilmiştir. Hakim olan bir görüşün, makalenin sonucunu destekler nitelikte olup, tüm bu akışı bilgisayarların ve yapay zekanın yürütebileceğini ileri sürerken; diğer bir görüşün ise muhasebe mesleği için bilgisayarların insanın yerini tutamayacağını savunmakta olduğu belirtilmiştir. Bu noktada bizlerce dikkat çekilmesi gereken durumun, dijital dönüşümün muhasebe mesleğine ilişkin bazı meslek gruplarının yerini alacağı; fakat bunun yanı sıra sistemi denetlemekle yükümlü yeni meslek gruplarının ortaya çıkmasının kaçınılmaz olacağı olarak dile getirilmiştir. Ayrıca günümüzde bu anlamda denetim mesleğinde ön plana çıkan CISA yani "Sertifikalı Bilgi Sistemleri Denetçisi" unvanının, konuyu özetlemek adına güzel bir emsal teşkil ettiği bildirilmiştir.

Günün ikinci oturumu Türkiye'de Muhasebe Eğitiminin Mevcut Durumu üzerine gerçekleştirilmiştir. Bu oturumun Başkanlığı: Prof. Dr. Cemal İbiş tarafından üstlenilmiştir. Oturumda toplam üç bildiri sunulmuştur: Bu oturumun ilk bildirisi olan "Dijital Bir Dünyada Muhasebenin Dönüşümü ve Yeni Eğilimler: Bulut ve Sosyal Medya" başlıklı bildiri Doç. Dr. Şebnem Yaşar tarafından sunulmuştur. Bildiride gelecekte model alınacak bir işletme dönüşüm yapısı üzerinde durularak, bu dönüşümün temel yapı taşları olan bulut iletişimi ve sosyal ağların katkıları tartışılmıştır. Web tabanlı bulut ağlarının gelecekte tüm dünya üzerinde faaliyetlerini sürdüren işletmelerin bir bütün haline gelerek karşllıklı iletişim ve etkileşim kurabilme yeteneğine sahip yeni yapıları oluşturma potansiyeli de bildiri sunumunda ele alınan bir başka tartışma unsuru olmuştur. $\mathrm{Bu}$ gelişmelerin sonucu olarak günümüzde muhasebecilerin kendilerini gelişen bu sürece nasıl adapte etmeleri gerektiğine dair bulguların saptanması ve sunumu ile bildirinin genel amaçları özetlenmiş ve bu doğrultuda muhasebe mesleği mensuplarının süreçteki rolleri tartışılarak bildiri sunumu tamamlanmıştır.

Oturumun devam eden bölümünde Dr. Öğretim Üyesi Burak Özdoğan ve Araştırma Görevlisi Batuhan F. Mollaoğulları tarafından hazırlanan "Muhasebe Eğitiminde Yetkinlik Arayışı: Uluslararası Eğitim Standartları ve Türkiye'de Muhasebe Eğitimi" başlıklı bildiri sunulmuştur. Bildirinin ana problem olgusu değişen ve gelişen ekonomik çevre içerisinde Türkiye'de gerçekleştirilen muhasebe uygulamalarının muhasebe bilgi kullanıcılarının ihtiyaçlarını yeterli ölçüde karşılayabilecek kaliteye sahip olup olmadığı olmuştur. Bu çalışma ile "2 No'lu Uluslararası Eğitim Standardı" kapsamında belirlenen "teknik yetkinliklere ve bu yetkinliklerin göstergesi olarak yayımlanan ögrenme çıktıları" ile Türkiye'deki üniversitelerde verilen muhasebe eğitiminin uyumluluğu irdelenmiştir. Araştırma probleminin analizi için 4 üniversite içerisinde bir çalışma yapıldığına değinilerek, çalışma sonuçlarının sunumu ile bildiri tamamlanmıştır. Bu sonuçlar dahilinde, Türkiye'de mevcut eğitim sisteminde farklı muhasebe programlarının mesleki yeterliliğe sahip bireyler yetiştirme potansiyelleri değerlenmiş, ders içeriklerinde bir yeniden gözden geçirme ihtiyacının mevcudiyeti belirtilerek bildiri sunumu tamamlanmıştır.

Oturumun son bildirisi olan "Muhasebe Eğitim Sürecinde Gereksinmeler" başlıklı bildiri Dr. Öğretim Üyesi Birsel Sabuncu'nun sunumu ile gerçekleştirilmişsir. Bildirinin giriş bölümünde Türkiye'deki mevcut muhasebe sisteminin durumu ve gereksinimlerinin neler olduğu konusu irdelenmiş, takip eden kısımda literatürde bugüne kadar yapılan çalışmaların sonuçlarına değinilmiştir. Bu kısmın akabinde bildiri muhasebe eğitimine ilişkin uluslararası eğitim standartlarının gereklerinin sunumu ile devam etmiş, bu gereksinimlerin belirlenmesinin ardından ülkemizdeki mevcut durumun bu ihtiyaçlarla olan örtüşümü ve sapmalarının incelenmesi gerçekleştirilmiştir. Bildiri sonuç kısmında "globalleşen dünya içinde muhasebe eğitimi ve muhasebe mesleği mensuplarının kendini güncelleme ihtiyacının ülkemiz içindeki önemi" tekrarlanmış ve bildiri bu ihtiyaçların sunumu ile tamamlanmıştır.

İkinci oturumun ardından gerçekleştirilen, "Muhasebe Eğitiminde Sinıf İçi Simülasyon Eğitimi”" sempozyumun en eğlenceli ve ilgi uyandıran kısımlarından biri olarak dikkat çekmiştir. Prof. Dr. Süleyman Yükçü tarafından hazırlanan simülasyon sunumu için bir de (biz) araştırma görevlilerinin katılımıyla gerçekleştirilen bir prova bir gün öncesinde tamamlanmıştır. Bu provanın ardından sunum ikinci günde gerçekleştirilmiştir. Bildirinin (biz) araştırma görevlileri için önemi de ayrıca onun bir parçası haline gelmemiz olmuştur. Muhtemelen katılan tüm araştırma görevlileri için böylesi bir deneyim bir ilk olarak yaşanmıştır. Simülasyon eğitimi Prof. Dr. Süleyman Yükçü 'nün renkli anlatımı ve katılan araştırma görevlilerinin maliyet unsurlarının birer parçası olması ile bir temsil şeklinde izleyenlere sunulmuştur. Burada ayrıca maliyet yöntemlerinin 
sınıf içinde bu tarz bir simülasyon modeli ile sunulması sonucunda eğitimde alınacak ek faydanın arttırılması ve gerçek hayatta fabrika ortamına giderek, maliyet muhasebesi unsurlarını yerinde gözlemleme imkanı bulamayan öğrencilere bir ölçüde gerçek hayat ortamının bir yansımasının oluşumu hedeflendiği bildirilmiş̧ir. Bu bildiride atlanılmaması gereken bir başka nokta da kıdemli hocaların da sunumda katılımo ılarak yer almış olmalarıdır. İzleyenlerle de aktif etkileşimin olduğu bu bildiri, sempozyumun ikinci gününde en uzun geçmesine karşın en çok ilgi gören bildirilerden biri olarak gerçekleştirilmiştir...

Takip eden oturum Prof. Dr. Ahmet Vecdi Can başkanlığında üç adet bildiri sunumu ile sürmüştür. Bu bildirilerden ilki olan “Türkiye’deki Üniversitelerin Muhasebe Eğitimi Açısından İncelenmesi” başlıklı bildiri Doç. Dr. Mustafa Gürol Durak, Dr. Öğretim Üyesi Ece Acar ve Dr. Öğretim Üyesi Bengü Yardımcı tarafından hazırlanmış, bildiri Dr. Öğretim Üyesi. Bengü Yardımcı tarafından sunulmuştur. Çalışmanın amacı Türkiye'de üniversitelerde verilen muhasebe eğitiminin içerik açısından incelenmesi olarak açıklanmıştır. Bu amaçla çalışmada 2018 yılı itibariyle faaliyette bulunan 206 üniversitenin lisans eğitimi programında bulunan derslerin içeriği incelenmiş ve söz konusu ders içeriklerinin geliştirilmesi ve düzenlenmesinde muhasebe eğitimi sempozyumlarında sunulan konuların katkıları irdelenmiştir. Sunumda devlet ve vakıf üniversitelerinin ayrı ayrı tahlilinin gerçekleştirildiği bilgisine yer verilmiş̧ir. Araştırmanın sonuç kısmında elde edilen tüm bulgular tablolar halinde sunulmuş ve farklı üniversitelerdeki müfredat içerikleri, programa alınma sıklıkları ve muhasebe eğitimi sempozyumunda yer bulma sıklığı açısından bu tablolar yardımı ile mukayese edilmiş, böylelikle bildiri sunumu tamamlanmıştır.

Bu oturumdaki ikinci bildiri ise Öğretim Görevlisi Tolga Yeşil tarafından hazırlanıp sunulmuştur. "Yönetim Muhasebesi Eğitiminde Standart Maliyet Yöntemi ve Doğrusal Programlama Iliş̧kisi” başlıklı bildiri, yönetim muhasebesi alanında kullanılan istatistiksel tekniklerden biri olan doğrusal programlamanın, standart bir maliyet oluşturmada kullanım kapasitesini değerlemiştir. Bildiride literatürde uygulanan farklı çalışmaların sonuçlarına da yer verilmiştir. Bildirinin devam eden kısmında dinleyiciler doğrusal programlama ve standart maliyet sistemleri hakkında bilgilendirilmiştir. Müteakiben bildiri sonuç bölümünde standart maliyet sistemi ve doğrusal programlamanın temel kesişim noktasının, yönetimsel süreçlerde karar alma aşaması olduğu vurgusu yapılmıştır. Son bölümde çalışmanın bu haliyle yeni çalışmalara ışık tutma amacının bulunduğu bilgisine yer verilerek bildiri sonuçlandırılmıştır.

Bu oturumun son bildirisi “Lisans Düzeyinde Muhasebe Ĕgitimi Alan Öğrencilerin Öğrenme Stillerinin Değerlendirilmesine Yönelik Bir Araştırma" başlı̆̆ ile sunulmuştur. Bildiri sahipleri Dr. Öğretim Üyesi Büşra Tosunoğlu, Doç. Dr. Selim Cengiz, Zafer Anadolu olarak belirtilmiştir. Bildiri sunumu Zafer Anadolu tarafından gerçekleştirilmiştir. Çalışmanın amacı "muhasebe eğitimi alan öğrencilerin genellikle hangi öğrenme stiline sahip olduğu ve öğrenme stillerinin öğrencilerin demografik özelliklerine göre farklılaşıp farklılaşmadığının araştırılması" olarak belirtilmiştir. Çalışmada dört adet hipotez değerlemesinin gerçekleştirildiği belirtilmiştir. Bu hipotezlerin tahlili için Çankırı Karatekin Üniversitesi İktisadi ve İdari Bilimler Fakültesi bünyesinde eğitim gören 126 öğrenci ile yapılan anketin sonuçlarının irdelendiği bildirinin giriş kısmında belirtilmiştir. Bildiride kullanılan araştırma yöntemleri ve anketlerin uygulandığı araştırma örnekleminin incelenmesi ve buna dair bilgiler bildiride ayrıntılı olarak açıklanmıştır. Bu veriler içinde katılımcıların cinsiyet, yaş, bölüm, sınıf, not ortalaması vb. yer almıştır. Bu veriler sunum içinde tablolar yardımıyla görseller yardımıyla analiz edilmiştir. Araştırmanın sonuç kısmında öğrencilerin farklı öğrenme stilleri yüzdeler halinde sunulmuş ve demografik özelliklerine göre oluşturulan hipotezlerin doğruluğu tartışılarak bildiri sunumu sonlandırılmıştır.

$\mathrm{Bu}$ oturumun sonrasında verilen bir aranın ardından bugünümüz oturumları 3. Oturum ile devam etmiştir. Prof. Dr. Selahattin Karabınar başkanlığında açılan oturumun ana başlı̆̆ı: "Türkiye'de Muhasebe Eğitiminin Mevcut Durumu" olarak belirlenmiştir. Bu başlık altında ilk sunum Dr. Öğr. Üyesi Anıl Gacar tarafından gerçekleştirilmiştir. Bildirinin başlı̆̆ı: "Fakültelerdeki İşletme Bölümlerinde Verilen Finansal Muhasebe Derslerinin İçerik ve Kapsam Yönünden Değerlendirilmesi: Devlet ve Vakıf Üniversiteleri Üzerine Bir Araştırma" olarak açıklanmıştır. Çalışmanın ana temasının Türkiye'de finansal muhasebe alanında verilen derslerin tahlili olduğunun belirtilmesinin ardından, bu değerlemenin yapılmasında Bologna Kriterlerinin çalışmada yol gösterici olduğu vurgulanmıştır. Avrupa ülkelerinin yükseköğretim alanında ortak bir çatı etrafında toplanması ve belli standartlar geliştirilmesi yönündeki çabalar sonucunda ortaya çıkan 
Bologna sürecinin, "artan bilimsel ve teknolojik gelişmeler doğrultusunda üniversitelerin daha nitelikli bireyler yetiştirmesini hedefleyen bir süreç" olarak tanımlandığı bilgisine yer verilmiştir. Bu kapsamda IAESB tarafından yayımlanan standartların sunumuna yer verilmiştir. Bu standartların değerlemesinde 129 devlet, 72 vakıf olmak üzere toplam 201 üniversitenin Bologna ölçütlerine göre hazırlanmış ders içeriklerinin tarandığı bilgisi verilmiş, yapılan içerik analizinin sonuçlarının bildirilmesi ile araştırma sunumu sonlandırılmıştır.

Takip eden sunumun başlığı benzer şekilde “Türkiye’de Muhasebe Ĕgitimi: Lisans Müfredatlarının İncelenmesi” olmuştur. Çalışma Dr. Öğr. Üyesi Büşra Tosunoğlu tarafından sunulmuştur. Giriş bölümünde çalışmanın amacının Türkiye'de muhasebe eğitiminin ve ders müfredatlarının incelenmesi olduğu belirtilmiştir. Bu amaçla çalışma Türkiye'de devlet ve vakıf üniversitelerinde müfredatta bulunan muhasebe derslerini doküman inceleme yöntemiyle taramıştır. Ayrıca çalışmada muhasebe meslek mensuplarıyla görüşmelere de yer verildiği sunumda belirtilmiştir. Yapılan tüm bu çalışmalar neticesinde bildiri sonunda muhasebe eğitimi için bir gelişim modeli önerilmiştir.

Oturumun üçüncü bildirisinde ise "Türkiye'de Muhasebe ve Muhasebe - Finansman Doktora Programlarındaki Derslere Yönelik Mevcut Durum Analizi ve Bir Model Önerisi” başlıklı bildiri Mustafa Oğuz tarafından sunulmuştur. Sunumun ilk kısmında Türkiye'de Muhasebe Finansman alanında mevcut olan doktora programlarının içeriği, hâlihazırdaki durumu ve bu programların içeriklerinin çeşitli avantaj ve dezavantajlarının üzerinde durulmuştur. Buna bağlı olarak müfredat içeriklerinin bir değerlemesinin yapılması ihtiyacı olduğu fikri ortaya atılmıştır. Bir kıyaslama yapılabilmesi için önceki bildirilerle benzer şekilde Eğitim Standartları içeriği üzerinde durulmuştur. Bu kriterlerin değerlemesi için, Türkiye’deki üniversiteler içindeki programların kalitesinin yabancı üniversitelerle karşılaştırılması ile elde edilen sonuçlar tablolar halinde sunulmuştur.

$\mathrm{Bu}$ otumdaki son bildiride ise yine Türkiye'deki üniversiteler içindeki muhasebe eğitiminin bir değerlemesi yapılmış ancak bu kez özellikli bir araştırma alanı olarak TR 33 bölgesi seçilmiştir. “2019'da Türkiye’nin Muhasebe Ĕgitimi ve Uygulamalarındaki Konumu ve TR 33 Bölgesinde Bir Uygulama” başlıklı bildiri Dr. Öğr. Üyesi İsmail Aydemir tarafından sunulmuştur. TR33 Bölgesi “Uşak, Manisa, Kütahya ve Afyon” illerini kapsadığı bilgisinin verilmesinin ardından çalışma amacı olarak 2019'da “Türkiye’nin maliyet ve yönetim muhasebesi eğitimi ve uygulamalarında, bütçe çalışmaları ve uygulamalarında, ne konumda olduğunun ortaya konması hedefi” açıklanmıştır. Yönetimsel süreçlerin açıklanabilmesi için grafik sunumlarından yararlanılmıştır. Araştırmada veri toplama tekniği olarak anket ve mülakat yöntemlerinden yararlanılmıştır. Bildiri sonuç kısmında araştırma sonucunda elde edilen veriler analiz edilerek uygulamalı muhasebe eğitimi konusunda mevcut eksiklikler ve bunların çözümüne dair öneriler sunulmuştur. Bu bildirinin ardından Prof. Dr. Fatih Coşkun Ertaş tarafından “Hayatın Renkleri Fotoğraf Sunumu” gerçekleştirilmiştir.

Günün son oturumu “Türkiye’de Muhasebe Eğitiminin Mevcut Durumu” başlı̆̆1 ile Oturum Başkanı Prof. Dr. Ümmühan Aslan tarafından yürütülmüştür. Oturumun ilk bildirisi: "Proje Yönetiminde Yeni Bir Yaklaşım Olarak Bütçesiz Yönetim Örneği: Çevik Model” olmuştur. Bildiri sahipleri Hüseyin Yeşil, Prof. Dr. Figen Öker Türüdüoğlu, Dr. Öğr. Üyesi Hümeyra Adıgüzel olarak açıklanmıştır. Bildiri sunum girişinde yönetim faaliyetlerinde amaçlara ulaşmada etkili olan çeşitli fonksiyonlar üzerinde durulmuştur. Bu fonksiyonların sağlıklı işlemesi için yönetim faaliyetlerinde bütçelerin yeri ve önemi vurgulanmıştır. Ancak son yıllarda bazı araştırmacıların ve uygulayıcıların, bütçelerin, günümüz organizasyonlarının hızla değişen iş ihtiyaçlarına cevap verme konusunda yetersiz kaldıklarını öne sürdükleri belirtilmiş ve "Bütçesiz Yönetim" anlayışının bu sebeple ortaya çıktığı belirtilmiştir. Yönetim muhasebesi alanında yapılan bu tartışmaların proje yönetimi alanına da yansımasıyla, yazılım geliştirme programlarının yönetiminde kullanılan geleneksel yöntemler üzerine başlatılan sorgulamaların sonucu olarak çalışmada iki farklı sistem olan: "Şelale” adı verilen geleneksel bir yöntem ile Geleneksel yöntemin eksik taraflarını ortadan kaldırmak için "Çevik” adıverilen yeni bir yazılım geliştirme yaklaşımının karşılaştırılması yapılmıştır. Sistemlere ilişkin getirilen açıklamalar sonucunda bu çalışma ile bütçesiz yönetim ile çevik yazılım geliştirme modeli arasındaki kavramsal benzerliklerin açıklığa kavuşturulduğu önerisi bildiri sonuç bölümünde açıklanmıştır.

Oturumun ikinci bildirisi “Muhasebe Eğitiminde Altı Şapka Düşünme Tekniğinin Kullanılması” başlığıyla Mehmet Günlük tarafından sunulmuştur. Çalışmada, "bir yaratıcı düşünmeyi geliştirme etkinliği olan "Altı Şapka Düşünme Tekniğinin" muhasebe eğitiminde kullanılması ele alınmıştır. Bu tekniğin ayrıntılı anlatımından önce muhasebe eğitiminin gereklilikleri 
üzerinde durularak, günümüzde mevcut eğitim sistemlerinin eksiklikleri tartışılmıştır. Bu eksikliklerin belirtilmesinin ardından Eğitimde Yaratıcı Düşünme ve 6 Şapka Düşünme Tekniği ile öğrencilere kazandırılması gereken eleştirel düşünme becerisinin uygulanabileceği alanlar belirtilmiştir. Araştırma sonuç bölümünde bu tekniğin muhasebe eğitiminde uygulanması sonucu elde edilen kazanımların neler olabileceği sorusu irdelenmiş, bu sorunun potansiyel cevaplarının neler olabileceği cevaplandırılarak bildiri sunumu sonlandırılmıştır.

$\mathrm{Bu}$ oturumun "Muhasebe Ĕğitimi Alan Lisans ve Ön lisans Mezunlarının İşletmelerin Beklentileri Açısından Değerlendirilmesi: Literatür Araştırması" başlıklı son bildirisi Tuğba Dölen ve Aydın Karapınar tarafından hazırlanmıştır. Araştırmada, muhasebe eğitimi alan lisans ve ön lisans mezunlarının işverenlerin bakış açılarından değerlenmesine yönelik son on yıldır yayınlanmış tüm makalelerin incelenmesi ve analiz edilmesinin amaçlandığı belirtilmiştir. Bunun için 20082018 yılları arasında yayınlanan çalışmaların sonuçları irdelenmiştir. Araştırma sonuçlarının sunumunda, çeşitli alanlarda bulunan yöneticilerin muhasebe meslek mensuplarından beklentileri sınıflandırılarak tablolar yardımıyla açıklanmıştır. Sonuç olarak üniversitelerde verilen eğitimin, sektörün ihtiyaç ve beklentilerini karşılayacak nitelikte mezunlar yetiştirme görevini en iyi şekilde yerine getirecek düzeyde yeniden yapılandırılması gerektiği vurgulanmıştır. Böylelikle gün içinde gerçekleştirilen oturumlar sonlandırılmıştır...

Gün sonunda gerçekleştirilen kıdemli hocalarla sohbet akşamı da ikinci günü sempozyumun en canlı günlerinden biri yapan bir başka kısım olmuştur. Burada kıdemli hocalar geçmiş tecrübe ve bilgilerini paylaşarak, Türkiye'de muhasebe eğitimindeki eksiklikleri ve gereksinimleri çeşitli yönleriyle ele almışlardır. Bu ciddi hava daha sonra yerini daha canlı ve ilgi çekici bir tartışma ve eski günleri yâd etme atmosferine bırakmıştır. Bu gecenin en önemli kazanımı belki de muhasebe eğitimindeki önemli bir alan olan para politikaları ve bunların nasıl idame edileceği konusu üzerine yapılan tartışma olmuştur. Bunun yanında tıpkı muhasebe eğitiminde simülasyon eğitimi bildirisi gibi bu bölüm de dinleyicilerin aktif olarak katılımcı haline geldiği ve böylelikle daha fazla ilgi çeken ve hatırda kalıcı bir etkinlik olarak gerçekleştirilmiştir.

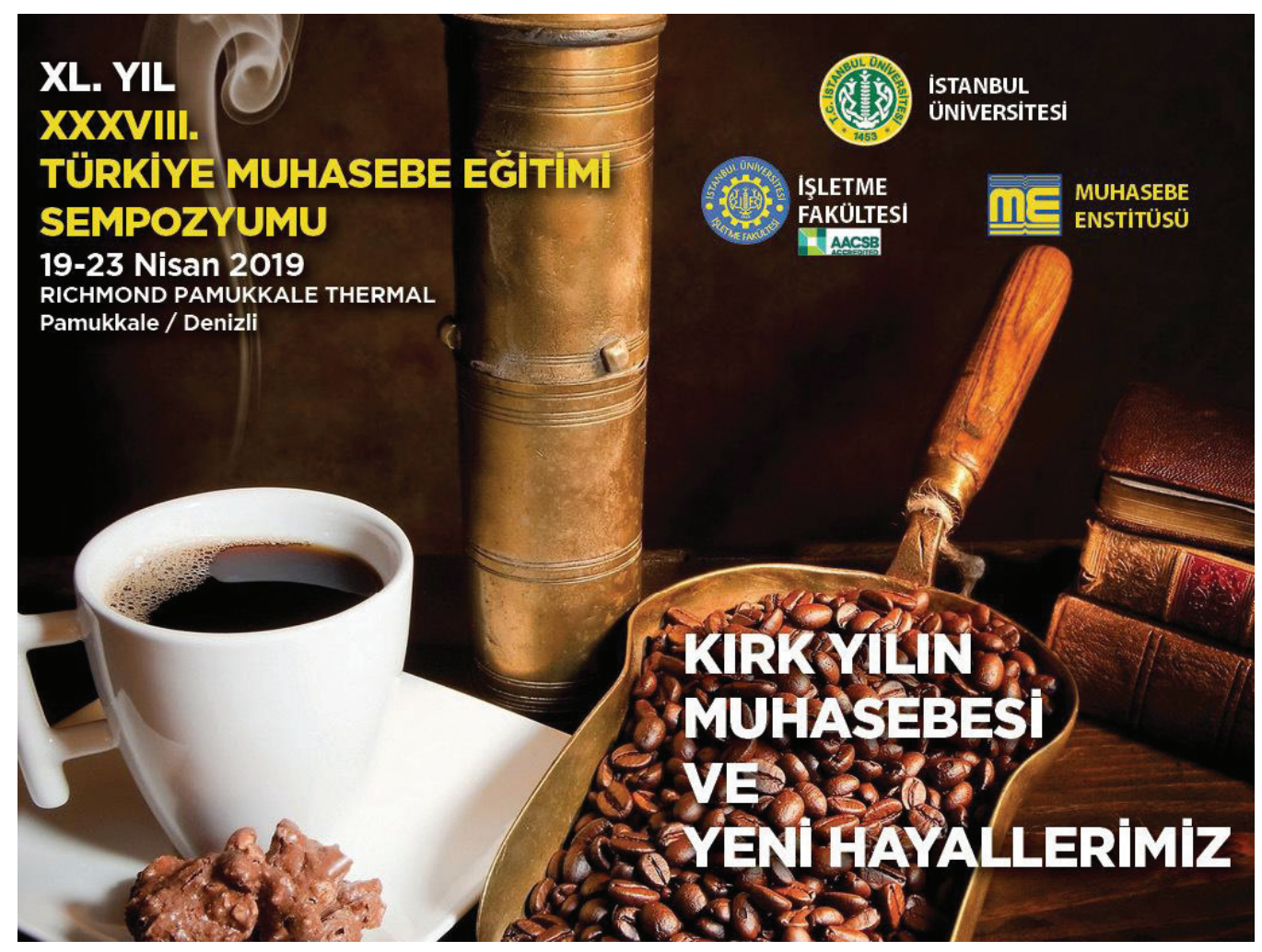

1979 yılında İstanbul Üniversitesi İşletme Fakültesi Muhasebe Enstitüsü’nün başlattığı ilk sempozyumda da oturumlar bir 20 Nisan günü başlamıştı. Sempozyum posteri, Muhasebe Enstitüsü’nce "bir fincan kahvenin kırk yı1 hatırı vardır” deyişinden esinlenerek dizayn edilmişti. 


\section{"HAYALLERIMIZ"}

38. Türkiye Muhasebe Eğitimi Sempozyumu'nun son günü olan üçüncü gününde Hayallerimiz temalı gerçekleştirilen Geleceğimiz Özel Oturumunda Prof. Dr. Ahmet Yüksel başkanlığında araştırma görevlileri olan Dr. Sinem Ateş, Nevzat Güngör ve Destan Halit Akbulut tarafından ‘Araştırma Görevlileri Paneli’ gerçekleştirilmiştir.

Panelde ilk olarak Dr. Sinem Ateş tarafından araştırma görevlilerinin görev tanımlarının net olmaması dolayısıyla araştırma görevlilerinin görevleri içine girebilecek sorumluklara ve girmemesi gereken sorumluluklara akademik birimlerde hangi ilgili yöneticinin karar vereceğine vurgu yapmış ve bununla beraber araştırma görevlilerinin asli görevi olan araştırma yapmak yerine çeşitli sekreterya görevlerini yerine getirmesinin araştırma görevlilerinin çok fazla sorumluluk altına girerek işine karşı içsel ve dişsal olarak olumsuz koşullanmasına neden olacağına dikkat çekmiştir.

Dr. Sinem Ateş'in ardından söz alan araştırma görevlisi Nevzat Güngör ise bilimsel araştırmalar konusunda YÖK ve TUBİTAK'ın öncelikli alanlarında muhasebenin bir bilim dalı olarak yer almamasının dezavantajlarından bahsetmiş ve muhasebe eğitimi için gerekli yurt dışı desteklerinin bulunmasının güçlüğüne değinmiştir. Ayrıca sektör deneyimi açısından araştırma görevlilerinin donatılması gerektiğini ve buna dair projelerin gerçekleştirilmesinin öneminden, dijitalleşme ile araştırma görevlilerine düşen sorumluluğun arttığından ve çeşitli teknolojik eğitimlerle de araştırma görevlilerinin yetkinliklerinin artırılması gerektiğine dikkat çekmiştir.

Nevzat Güngör'ün ardından söz alan araştırma görevlisi Destan Halit Akbulut ise akademilerdeki araştırmaların niteliğini artırmak, akademik değişimleri kolaylaştırmak ve diplomaların ve ünvanların karşılaştırılabilirliğine yardımcı olmak ve başka bir çok faydası olan akreditasyonun üniversiteler için gerekliliğinden bahsetmiş ve araştırma görevlilerinin araştırma yetkinliği dışında iyi bir eğitimci yetkinliğine de sahip olması açısından formasyon eğitimi almalarının büyük fayda sağlayacağına dikkat çekmiştir.

Araştırma Görevlileri Paneli'nin ardından Türkiye'de Muhasebenin ve Muhasebe Eğitiminin Geleceği teması altında iki oturum gerçekleşmiş ve her oturumda 3'er bildiri sunulmuştur.

İlk oturum Prof. Dr. Semra Öncü başkanlığında yürütülen “Türkiye’de İç Denetimin Dünü, Bugünü ve Yarını: TİDE’nin İç Denetimin Gelişimi ve Geleceğindeki Rolü” başlıklı ilk bildiri TİDE Yönetim Kurulu Üyesi ve Uğur Okulları İç Denetim Müdürü olan Ethem Yenigün tarafından sunulmuştur. Bildiride küreselleşme ve teknolojik dönüşümlerle gerçekleşen hızlı değişim ve artan risklerin iç denetime olan ihtiyacı artırmasıyla birlikte iç denetim alanında da değişimlerin yaşanmasını zorunlu kıldığından bahsedilmiş ve iç denetimin bu değişimin içerisinde yer alabilmesi için yeni ve bütüncül bir yaklaşımla küresel temelde tasarlanarak geliştirilmesi gerektiğine vurgu yapılmıştır. Ethem Yenigün, bu değişimde TİDE’nin önemli bir rolü olacağından ve iç denetim anlayışının günümüzdeki noktaya gelmesinde TİDE tarafından gerçekleştirilen faaliyetlerin öneminden bahsetmiş, TİDE’nin hem ulusal hem de uluslararası alanda dönüşüme liderlik edebilecek faaliyetleri, kurumsal yapısı ve yarattığı değerler ile iç denetimin dönüşümüne liderlik yapabileceğine ve diğer örgüt ve enstitülere bu konuda örnek olacağına dikkat çekmiştir.

İlk oturumun ikinci bildirisi olan “Z Kuşağının Muhasebe Eğitimi: Muhasebe 4.0” başlıklı bildiri Dr. Şafak Ağdeniz tarafından sunulmuştur. Bu bildiride günümüzde yaşanan dijital dönüşümün hayatımızın her alanını etkilediği gibi muhasebe mesleğine ve öğrencilerine olan etkilerinden de yola çıkarak nasıl bir muhasebe eğitimi verilmesi gerektiğine odaklanılmıştır. Bununla beraber dijitalleşme ile iç içe doğan Z kuşağının yine bu dijitalleşmenin içerisinde var olduğu bir muhasebe eğitimine ihtiyaç duyduğuna dikkat çekilerek muhasebe eğitiminin verilmesinde çeşitli değişikliklerin ve gelişmelerin takip edilmesinin gerekliliği vurgulanmıştır. Yeni bir müfredat önerisi ile birlikte birçok öneri sunulmuş ancak saha araştırması yapılmamıştır.

İlk oturumun üçüncü bildirisi olan "Muhasebe Eğitiminde Yeni Teknolojiler: Hologram Tekniğgi” başlıklı bildiri Prof. Dr. Süleyman Uyar tarafından sunulmuştur. Bu bildiride bilgi ve iletişim teknolojilerindeki gelişmelerin eğitim alanında geleneksel eğitim yöntemlerinin terkedilerek yeni yöntemlerin eğitim sürecinde var olmasına imkan sağladığından bahsedilmiştir. $\mathrm{Bu}$ yeni eğitim tekniklerinden biri olan hologram tekniğinin yeni eğitim yöntemlerinden olan uzaktan 
eğitim ve e-eğitim gibi yöntemleri zayıfladığında ön plana çıkacă̆ına dikkat çekilmiş ve hologram teknolojisinin muhasebe eğitiminde kullanılmasıyla muhasebe eğitimine kazandıracağı avantajlara vurgu yapılmıştır.

İkinci oturum Prof. Dr. Dursun Arıkboğa başkanlığında yürütülen "Günümüz Muhasebe ve Denetim Eğitimi Perspektifinden Geleceğin Denetim Anlayışına Bakış: Karşılaştırmalı Bir Araştırma” başlıklı ilk bildiri Dr. Öğretim Üyesi Mahmut Sami Öztürk tarafından sunulmuştur. Bu bildiride gelecekteki denetim uygulamaları temelinde öğrencilerin ve denetçilerin muhasebe ve denetim konusundaki algı seviyeleri ölçülmeye çalışılmış ve benzer görüşlere sahip oldukları dikkat çekmiştir. Ayrıca öğrencilerin ve denetçilerin görüşlerinin dijital çağa uyum sağlayacak bir muhasebe eğitim sisteminin oluşturulması amacıyla programlama dillerinin, yazılımların, paket programların vb. müfredatlara eklenmesi ve gerekli eğitimlerin meslek mensuplarına biran önce verilmesinin gerekli olduğu ortaya çıkarılmıştır.

İkinci oturumun ikinci bildirisi olan "Endüstriyel 4.0.'te Muhasebeci ve Muhasebe" başlıklı bildiri Doç. Dr. İpek Türker tarafından sunulmuştur. Bu bildiride bilgi teknolojileri ve bilgiye erişimin yöntemlerinin sürekli olarak değişmesinin kaçınılmaz olarak muhasebeyi ve muhasebe mesleğini icra eden muhasebecileri etkilediğinden bahsedilmiş, endüstri 4.0 içinde muhasebe mesleğinin gelişimi, meslek kalitesi ve meslek mensubunun değerindeki artış üzerinden incelenmiştir. Teknolojik gelişmelerin zaman açısından sağladığı maliyet faydasını muhasebe içerisinde de görmek ve kullanmak her ne kadar isteniyor ve uygulamaya çalışl1yyor olsa da big data, blokchain, bulut sistemlerine muhasebe mesleğinin sonunu getireceği yargısıyla yaklaşılmasının doğru bir bakış açısı olmadığı, insanoğlunun deneyimle elde ettiği bilginin makinelerden, yapay zekalardan daha değerli ve kullanışlı olduğuna vurgu yapılmıştır.

İlk oturumun üçüncü bildirisi olan Muhasebe Mesleği’ nin Geleceği ve Gelecek İçin Öğrenme Metodları başlıklı bildiri ACCA Türkiye Başkanı Filiz Demiröz tarafından sunulmuştur. Filiz Demiröz muhasebe mesleğinin gelecekte nasıl yürütüleceğine, muhasebeyi öğrenmek ve öğretebilmek için gelecekte sahip olunması gereken yetkinliklere dikkat çekerek şimdiden geleceğe ilişkin hazırlıklar yaparak teknolojiyi ve değişimi hayatımızın ayrılamaz bir parçası olarak devam etmemiz gerektiğini vurgulamıştır.

Bildiri sunumlarının ardından gerçekleşen Kapanış Paneli Prof. Dr. Mehmet Emin Arat başkanlığında Mikro Yazılım Genel Müdürü Alpaslan Tomuş, Kamu Gözetimi Muhasebe ve Denetim Standartları Kurulu Uzmanı Fatih Selçuk, Prof. Dr. İdil Kaya ve Prof. Dr. Ülkü Ergun'un konuşmalarıyla devam etmiştir. Bu konuşmaların buluştuğu ortak payda, muhasebe eğitiminde ve muhasebe mesleğinin yürütülmesinde teknolojik değişimleri göz ardı etmeden, değişime ayak uydurarak yeni yöntem ve tekniklerle muhasebenin de gelişimine ortak olunması gerektiğidir.

38. Türkiye Muhasebe Eğitimi Sempozyumu'nun kapanış konuşması Muhasebe Enstitüsü Müdürü Göksel Yücel tarafından yapılmış ve muhasebe eğitimi sempozyumunun 40. yılına dikkat çekerek tüm muhasebe dünyasına bu geleneği sürdürdükleri için teşekkür etmiş ve Sempozyum Kurulu üyelerine, İstanbul Üniversitesi İşletme Fakültesi Muhasebe Anabilim Dalı öğretim kadrosuna ve geçmişte Muhasebe Enstitüsüne emek veren Dr. Tülay Aner’e, Prof. Dr. Peyami Çarıkçığlu’na, Prof. Dr. Ahmet Yüksel'e, Prof. Dr. Cengiz Erdamar’a ve Prof. Dr. Mustafa A. Aysan’a şükranlarını sunmuştur.

39. Türkiye Muhasebe Eğitimi Sempozyumunu üstlenen Burdur Mehmet Akif Ersoy Üniversitesi Rektör Yardımcısı Prof. Dr. Durmuş Acar sahneye davet edilerek muhasebe eğitimi sempozyumlarını başlatan Prof. Dr. Mustafa A. Aysan tarafından sempozyum bayrağı teslim edilmiş ve hatıra fotoğrafının ardından sempozyum sona ermiştir.

\section{Sonuç}

1979 yılında yapılan sempozyumda kimlerin acı kahve içtiğini bilmesek de içilen acı kahvelerin kırk yıllık hatırını 2019 yılında Denizli'de görmek, Türkiye Muhasebe Eğitim Sempozyumunun akademik hayatımızda ne kadar önemli olduğunu göstermesi bakımından önemliydi. Sempozyumun kırkıncı yılında ülkemizin değişik coğrafyalarından 200’ün üzerinde katılımcı ile düzenlenmiş olması bu sempozyumun köklerinin ne kadar sağlam atıldığının bir göstergesi olsa gerektir. Sempozyuma katılan çok sayıdaki genç akademisyenin varlığı da Türkiye Muhasebe Eğitim Sempozyumları için nice kırk yıllarının olacağını gösteren bir ışık olmuştur.

Finansal Destek: Yazarlar bu çalışma için finansal destek almamışlardır. 


\section{Kaynakça}

Kırk Yılın Muhasebesi ve Yeni Hayallerimiz, Sempozyum Bildiri Kitabı, XXXVIII. Türkiye Muhasebe Eğitimi Sempozyumu, 19-23 Nisan 2019. 